\title{
掘削溝の肩付近に現れる崩壊予兆に関する 実大模型実験
}

\author{
玉手 聡 1 堀 智仁 2 \\ 1正会員 独立行政法人 労働者健康安全機構 労働安全衛生総合研究所 研究推進・国際センター \\ （三204-0024 東京都清瀬市梅園1-4-6） \\ E-mail: tamate@s.jniosh.go.jp \\ 2正会員 独立行政法人 労働者健康安全機構 労働安全衛生総合研究所建設安全研究グループ（同上） \\ E-mail: horito@s.jniosh.go.jp
}

\begin{abstract}
地盤を表面から溝状に掘削する溝掘削工事では土砂の生き埋めとなる事故が後を絶たない. その直接的 な原因は本来設置されるべき土止め支保工が適切に設置されていなかったことであるが，人的被害の背景 には崩壊の予兆に気づかず逃げ遅れたことがある。本研究では地山の安定を過信しがちなクリープ的崩壊 に焦点をあて，その危険増加を計測によって把握する方法を実験的に調查した。特に簡易計測の観点から 浅い部分のせん断ひずみ増加に着目し, 溝の肩付近で計測したところ沈下や傾斜と連動した反応が見られ た. その值は掘削終了後も継続した増加を示し, クリープ的な変化が崩壊予兆として捉えられた. 本報告 では溝の肩付近のせん断ひずみを簡易計測する技術と崩壊の危険検出について述べる.
\end{abstract}

Key Words: trench, excavation, failure, monitoring, shear strain, centrifuge model test, full scale model test

\section{1. はじめに}

土砂崩壊による生き埋め事故は後を絶たず年間10人か ら20人の作業者が被災している. 発生状況を調査すると 請負金額が4000万円以下の工事が約半数を占め，工事体 制は人数が6名以下の作業が6割以上と多い1). したがっ て，労災事故は小規模な工事で多く発生している．また， 厚生労働省が発表した平成27年の災害統計によれば，土 木工事による死傷者3956人のうち事故の型が「崩壊・倒 壊」に分類されるものは190人であり，さらに，「事故 の起因物(小分類)」では「地山・岩石」が199人と上位を 占める。このように，地山の崩壊に関係する事故は多く 発生しており，その対策は急務な現状である.

労働安全衛生規則2)(以下，規則という)では手堀り掘削 時の地山の高さと勾配の関係を表-1のように示している. ここで「地山の種類」にある「堅い粘土」とはN值が8 以上と定義され，また「崩壊しやすい状態」は大発破に より緩められた地山, 大規模な崩壊のため落下し, 堆積 している岩石からなる地山等とされている. そのため, 一般の施工では「その他の地山」として計画され，深さ $2 \mathrm{~m}$ では垂直に掘削されることが多い，また，同規則 では「地山の崩壊等による危険の防止」として崩壊のお
それがある場合の防止措置を義務付け，また，厚生労働 省基発第1217001号「土止め先行工法に関するガイドラ イン」(平成15年12月17日)では未補強な溝内に作業者が 進入しないよう指導している. ここで土止め先行工法と は溝内での作業に先行して土止め支保工を設置する工法 のことである3.

施工の現状や課題について，規模が異なる数社の技術 者と作業者に面談してヒヤリングしたところ溝掘削では 既設埋設物の確認が必要な場合があり，その際は一時的 に溝内へ入らざるをえないとの話が聞かれた。 また，ユ ニット化された土止め機材は重量が重くその設置には相 応の移動式クレーンが必要となるが小規模工事では敷地 の制約やコストがハードルとなる.さらに，軟弱な地盤 では土止めに作用する壁面摩擦が大きくなってユニット ごとの撤去は難しい場合がある. 加えて，掘削後に自立 する地山は一見安定していることから「崩壊のおそれ」 に気づきにくいとの指摘があった.

以上のように，同種災害の防止には土止め先行工法の 一層の普及を図ると共に補助工法の開発も含めた技術的 解決が必要と考えられる. これに加えて，工学的に必ず しも明確となっていない「崩壊のおそれ」を具体化でき れば，人的被害を軽減できる可能性がある，すなわち， 
表-1 地山の種類による掘削面の高さと勾配の基準2)

\begin{tabular}{c|c|c}
\hline 地山の種類 & 掘削面の高さ & 掘削面の勾配 \\
\hline 岩盤または堅い & $5 \mathrm{~m}$ 未満 & 90 度 \\
\cline { 2 - 3 } 粘土からな地山 & $5 \mathrm{~m}$ 以上 & 75 度 \\
\hline \multirow{2}{*}{ その他の地山 } & $2 \mathrm{~m}$ 未満 & 90 度 \\
\cline { 2 - 3 } & $2 \mathrm{~m}$ 以上 $5 \mathrm{~m}$ 未満 & 75 度 \\
\cline { 2 - 3 } & $5 \mathrm{~m}$ 以上 & 60 度 \\
\hline 砂からなる地山 & $5 \mathrm{~m}$ 未満または 35度以下 \\
\hline 崩壊しやすい状態 \\
になっている地山
\end{tabular}

表-2 実験に使用した関東ロームの物理特性

\begin{tabular}{c|c}
\hline 土粒子密度 $\rho_{\mathrm{s}}\left(\mathrm{g} / \mathrm{cm}^{3}\right)$ & 2.759 \\
砂 $(0.075 \sim 2 \mathrm{~mm}) \%$ & 6.2 \\
シルト $(0.005 \sim 0.075 \mathrm{~mm}) \%$ & 45.3 \\
粘土 $(0.005 \mathrm{~mm}$ 未満 $) \%$ & 48.5 \\
液性限界 $w_{\mathrm{L}}(\%)$ & 158.3 \\
塑性限界 $w_{\mathrm{p}}(\%)$ & 97.7 \\
塑性指数 $I_{\mathrm{p}}$ & 60.6 \\
最大乾燥密度 $\rho_{\mathrm{m} \text { max }}\left(\mathrm{g} / \mathrm{cm}^{3}\right)$ & 0.665 \\
最適含水比 $w_{\text {opt }}(\%)$ & 102.0 \\
\hline
\end{tabular}

表-3 建設機械による締固め条件

\begin{tabular}{c|c|c|c|c}
\hline 重量 & 作業半径 & 載荷荷重 & バケットの & 締固め圧力 \\
$W$ & $R$ & $F$ & 載荷面積 $A$ & $p(=F / A)$ \\
\hline $116 \mathrm{kN}$ & $3.5 \mathrm{~m}$ & $33.8 \mathrm{kN}$ & $0.9 \mathrm{~m} \times 1.6 \mathrm{~m}$ & $23 \mathrm{kN} / \mathrm{m}^{2}$ \\
\hline
\end{tabular}

安全性の向上には「崩壊させないこと」だけではなく 「崩壊を想定して備えること」も大切であり，危険を事 前に察知寸ることによって人的被害を軽減できる可能性 がある.そこで本研究では，崩壊危険の事前把握を目的 に実大模型実験を行った. 具体的には目視で崩壊危険を 把握できるか確かめるとともに，電気的センサーは危険 低減に有効か実験的に調査した. 計測には本研究で開発 中のセンサーと既往のものの計3種類を用い，計測箇所 は先のガイドラインの「地山の点検」4に示された「溝 の肩」付近とした。本報告では, 溝崩壊の危険把握に対 する計測的手法の可能性について実験的に考察する.

\section{2. 遠心模型実験による限界高さの予備的調査}

後述する実大模型実験に先立って遠心模型実験を行っ た. その目的は掘削溝の限界高さと崩壊範囲を予備的に 調査することであった．両実験に用いた土試料は関東口 一ムでありその物理特性を表-2 に示寸，遠心模型実験 では含水比 105.9\%に調整した土試料を $25 \mathrm{kPa}$ で静的に 締め固めて模擬洅斜面を作製した．同一の締固め条件で 作製した供試体の一軸圧縮強さは約 $10 \mathrm{kN} / \mathrm{m}^{2}$ である.

模擬溝斜面は締め固めた土試料をストレートエッジで 削り出して図-1(b)のように作製した。これは，図-1(a)に

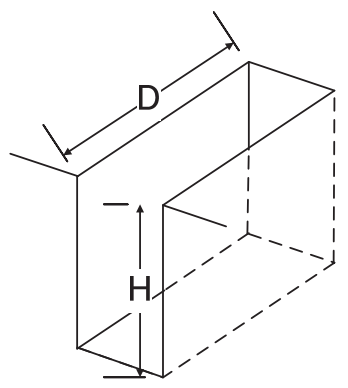

(a) 掘削溝

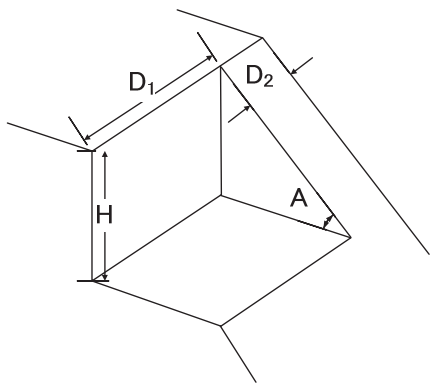

(b) 模擬溝斜面 図-1＼cjkstart遠心実験のためのモデル化

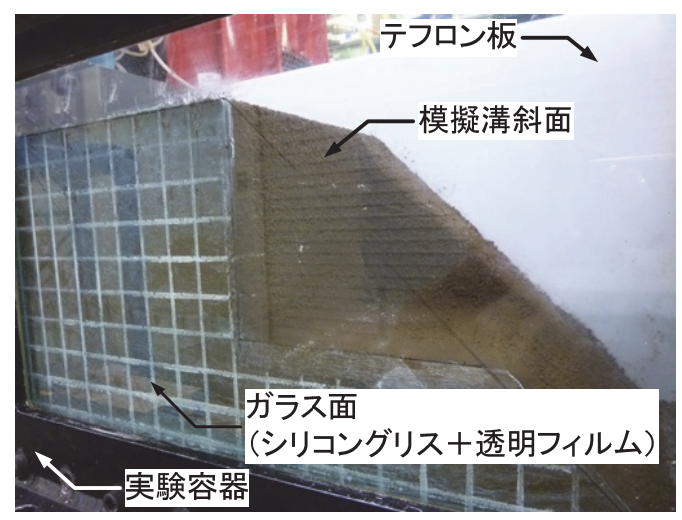

図-2 模擬溝斜面の外観

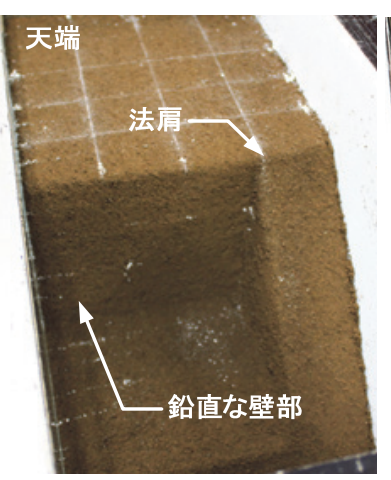

(a) 崩壊前

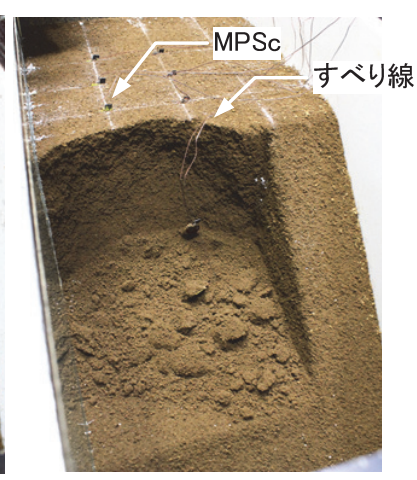

(b) 崩壊後
図-3 模擬溝斜面の崩壊前後の比較

示寸掘削溝の片壁部分を再現したものである.この模擬 溝斜面は後述する実大斜面とほぼ相似なものである. 斜 面の寸法は模擬溝に相当する鉛直部分の幅 $D_{1}$ が $150 \mathrm{~mm}$, 斜面部分 $D_{2}$ が $50 \mathrm{~mm}$, 深さ $H$ は $135 \mathrm{~mm}$ である.また, 斜面部の勾配 $A$ は 45 度である.

図-2 は容器内に作製した模擬溝斜面を示寸，奥側の 壁面にはテフロン板を配置した. 手前側のガラス面には シリコングリースを塗布し，さらに帯状にカットした透 明フィルムを配置した．以上のように容器の壁面では土 との間に生じる摩擦を低減させた.

図-3 は模擬溝斜面の様子を崩壊前後で比較する. 遠 心加速度を徐々に増加させたところ 20.7g で図-3 (b)のよ うに鉛直の壁部分が薄く崩落した. 天端に現れたすべり 


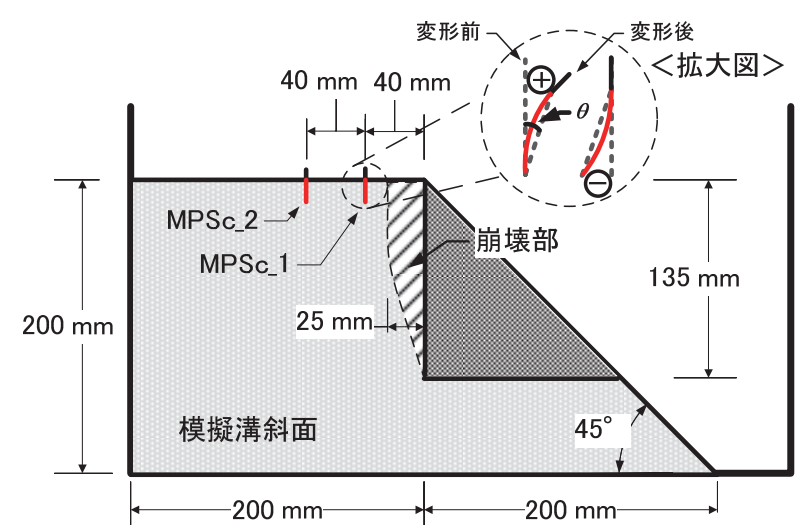

図-4 遠心模型実験の模擬溝斜面の断面図

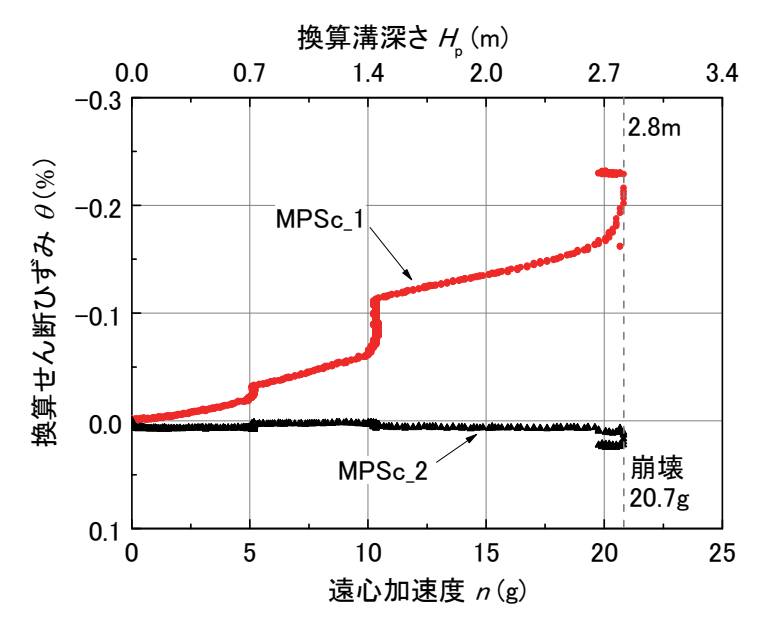

図-5 遠心加速度と換算せん断ひずみの関係

線は法肩から曲線を呈しておりその最大奥行きは図-4の ように $25 \mathrm{~mm}$ であった。 法肩から $40 \mathrm{~mm} と 80 \mathrm{~mm}$ 位置に は4章で後述する「表層ひずみ棒」を遠心実験用に小型 化したセンサー(以下，MPScと言う)を設置した。

図-5はMPScの換算せん断ひずみ $\theta \%$ 5) のと遠心加速度 $n \mathrm{~g}$ の関係を示す.上の横軸には $H$ に $n$ を乗じて求めた 換算溝深さ $H_{\mathrm{p}}$ を示す. $n$ の増加に伴って MPSc_1の日は 負の増加を示している. これは図-4 内に拡大して示し たマイナス(一)側の変形が $n$ とともに増加したことを意 味する.

法肩に近い側に設置された MPSc_1 の増加は MPSc_2 よりも大きい.これは，崩壊部に接近した部分ではせん 断ひずみの増加が大きかったことを示している.

MPSc_1は $n$ が $20 \mathrm{~g}$ 以降に $\theta$ が急増しており, 模擬溝斜面 の不安定化が捉えられている. 崩壊は $20.7 \mathrm{~g}$ で発生し, $H_{\mathrm{p}}$ の限界高さは約 $2.8 \mathrm{~m}$ であった.

\section{3. 土試料の締固めと実大斜面による溝掘削の模擬}

実大斜面の作製では土試料を耕運機で可能な限り細か くほぐした上で散水と攪拌を繰り返して含水比 $\omega$ を調整

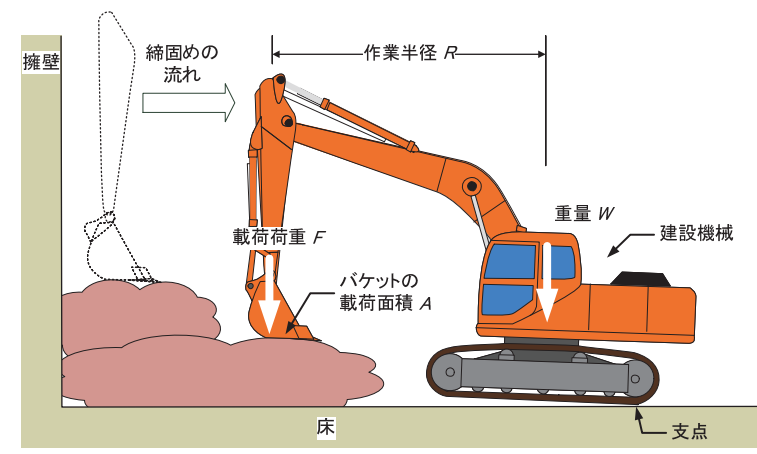

図-6＼cjkstart建設機械のバケットによる土試料の締固め

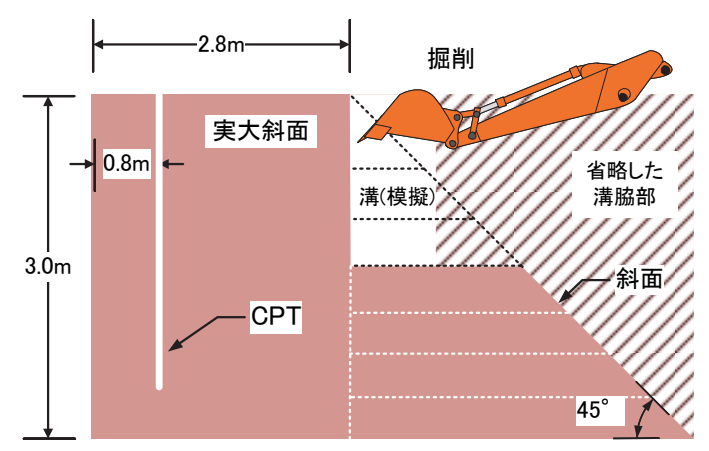

図-7 溝掘削を模擬する斜面掘削の方法

した(増加させた). しかしながら，調整後の心は約90\%で ありこの值は最適含水比 $\omega_{\text {opt }}$ りも約 $10 \%$ 低い值であつ た. 当初の計画では $\omega_{\text {opt}}$ 目標としたがブロック化した 試料部分が多く，これ以上ほぐし作業と含水比調整を行 うことは困難と判断し，計画を変更した。

これは見かけ上の $\omega$ 無理に $\omega_{\mathrm{opt}}$ と同じになるまで加 水すると「ほぐれた土」の含水比と「ブロック化した 土」の含水比の差が大きくなるためである. すなわち, ほぐれた土の $\omega$ が $\omega_{\mathrm{op}}$ 以上になるとその部分だけが極端 に軟化し地山全体を不安定化させる懸念があったためで ある.

土試料は擁壁に囲まれた部分に厚さ $0.3 \mathrm{~m}$ 程度で均等 に撒きだし，その土試料を建設機械のバケット背面で図 -6のように静的に圧縮して締固めた.ここで，擁壁と実 大斜面の間には摩擦を軽減するためにポリエチレンシー トを3面に配置した. 締固めでは作業半径R(バケットと 旋回中心の間の距離)がほぼ3.5 mとなるようにした.ま た，クローラは後ろ側駆動輪を支点として前側の従動輪 が軽く浮き上がった状態となるようにバケットで支持さ せた.これは機体の重量Wによって生じる転倒モーメン トをバケットのみで支持させることで土試料に作用する 載荷荷重Fを一定させ, 土のせん断強さの変動を小さく するためであった.

表-3に建設機械による締固め条件を示す．本実験に使 用した建設機械はWが116 kNであり，その他の諸元を基 に計算したFは33.8kNであった。締固めの際にはバケッ 


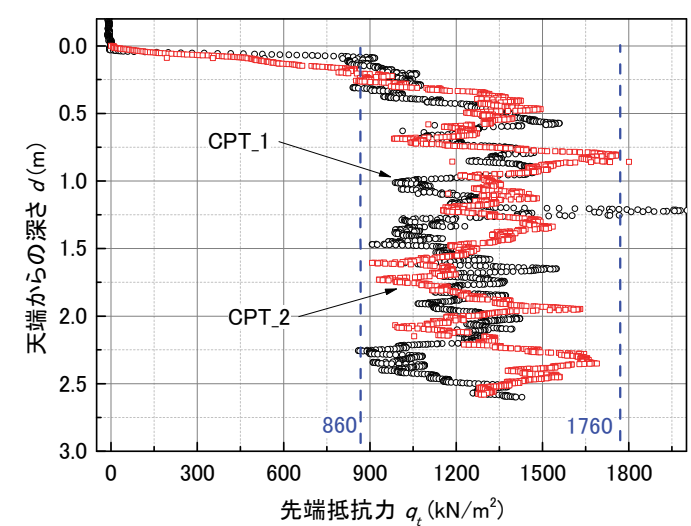

図-8 実大斜面におけるコーンの先端抵抗力の分布

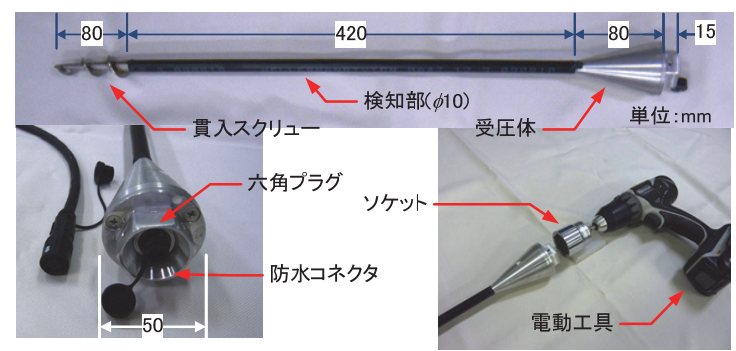

図-9＼cjkstart表層ひずみ棒(MPS)の寸法と外観

トを標準搭載のものからオプションの「法面バケット」 に交換した．これは法面バケットの背面が平面であるた め土試料に均等な圧力を作用できるためである．その載 荷面積 $A$ は $0.9 \mathrm{~m} \times 1.6 \mathrm{~m}=1.44 \mathrm{~m}^{2}$ であり, 締固め圧力 $p$ 計 算値は23 kN/m²であった. この值は遠心模型実験の模擬 溝斜面の $p\left(=25 \mathrm{kN} / \mathrm{m}^{2}\right)$ とほぼ同じである.

図-6に示すように擁壁奥側から盛土と締固めを繰り返 して高さ3.0 mの実大斜面を作製した。 天端は図-7のとお り奥行き $2.8 \mathrm{~m}$ であり，手前側には勾配45度の斜面が連続 している. 天端では電気式コーンによる貫入試験(CPT) を行った．その実施位置は図-7と後述する図-11(b)に示 すように擁壁背面から $0.8 \mathrm{~m}$ 離隔を有する2つの列の R10 と L10上の2箇所であった。用いたコーンは直径が $25.4 \mathrm{~mm}$ ，先端角は60度の円錐であり，貫入速度は約 15 mm/秒であった。

図-8は実大斜面の天端からの深さ $d$ と先端抵抗力 $q_{t}$ の関 係を示す. $d>0.5 \mathrm{~m}$ ではqが大きな増減を示しており, 盛土内にブロック化して存在した土試料の影響が顕著に 現れている. $0.5 \mathrm{~m}<d<2.5 \mathrm{~m}$ ではqが860 kN/ $\mathrm{m}^{2}<q_{\mathrm{t}}<1760$ $\mathrm{kN} / \mathrm{m}^{2}$ で変動している. その最小值は盛土内に存在する ほぐれた土による抵抗を表し, 最大值はブロック化した 土のqt示すと考えられる.

このように硬くブロック化した原因は土試料の調整手 順に問題があったためと考えている. 今回は「ほぐし 前」の土試料の含水比が高すぎたためにバケットの攪拌 によって逆に一部が締め固まってブロック化した. 今後,

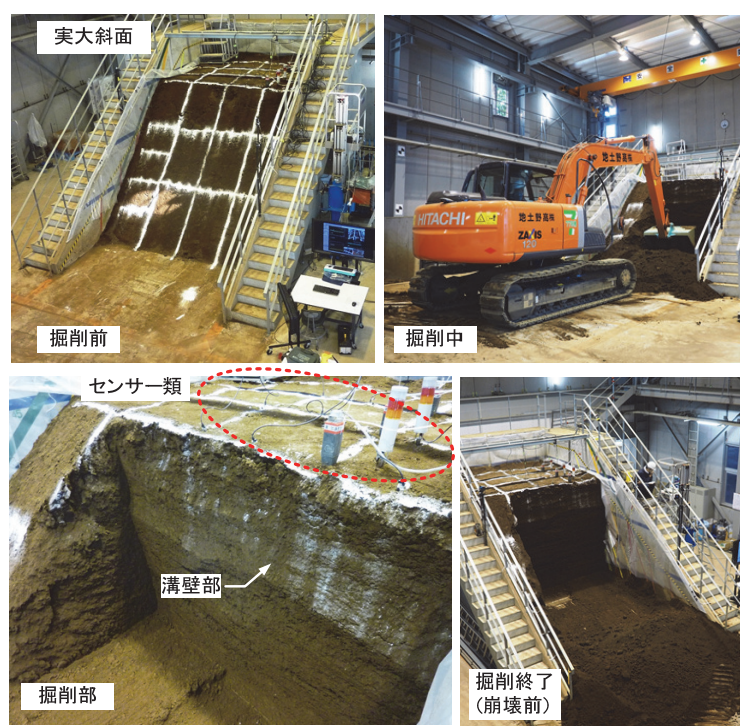

図-10 実大斜面を部分掘削する様子

\begin{tabular}{|c|c|c|}
\hline センサー記号 & 計測項目 & 応答感度 \\
\hline ASG & 傾 斜角 & $0.1124 \mathrm{deg} / \mu \varepsilon$ \\
\hline DTP & 変位 & $0.05 \mathrm{~mm} / \mu \varepsilon$ \\
\hline MPS & せん断ひずみ & $0.0015 \% / \mu \varepsilon$ \\
\hline
\end{tabular}

同種の実験では含水比が低い状態で十分ほぐし，その後， 含水比を増加させることが適当と思われる.

本研究では溝掘削を斜面掘削によって簡易的に模擬す ることとし，図-7と図-10に示すように，斜面の部分を 建設機械によって法肩から鉛直に掘削した．したがって， 鈆直な壁部を増加させることによって溝掘削を模擬した. センサーによる計測項目を表-4に示す. 計測箇所は先 に述べたとおり溝の肩付近であり，センサーは掘削開始 前に設置した。

\section{4. 肩付近での計測方法と崩壊の様子}

\section{(1) 表層ひずみ棒によるせん断ひずみ増加の計測}

地表面付近で変化するせん断ひずみの増加を計測する ために表層ひずみ棒》(以下，MPS之言う)を設置した。 MPSは地面に回転貫入して設置するセンサーであり，本 体部分にある棒の曲げ変形によってせん断ひずみの増加 を捉えるものである $)^{8}$. 図-9はMPSの外観を示す. MPS は全長 $595 \mathrm{~mm}$, 最小直径(パイプ) $10 \mathrm{~mm}$, 最大直径(受圧 体)50 mm, 質量約 $3.6 \mathrm{~N}$ の小型のセンサーである9). 先端 には長さ $80 \mathrm{~mm}$ 貫入スクリューが備わり，その羽根の 高さは最大 $5 \mathrm{~mm}$ ，ピッチは平均 $30 \mathrm{~mm}$ となっいる. 設 置ではプレボーリングを必要とせず直接貫入できるため 地山を緩めない。 むしろ貫入時には土が押し広げられる ため, MPSは地山と強く密着する効果が期待される.こ れまでの実験では崩壊前の変化が計測されており，その 


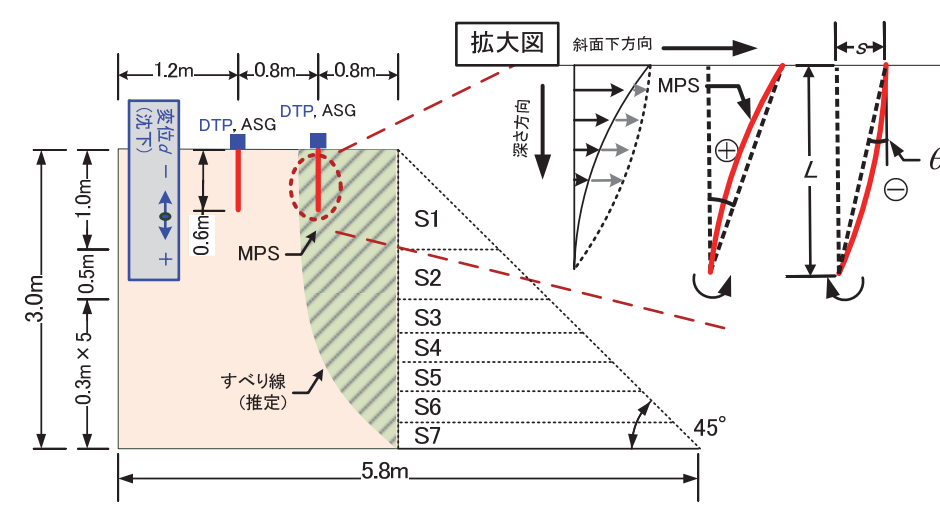

(a) 立面図

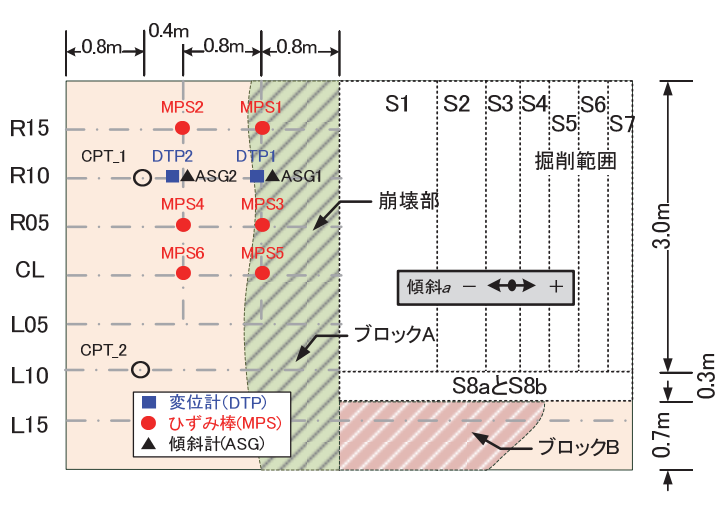

(b) 平面戝

図-11 実大斜面における部分掘削の位置と計測センサーの設置位置

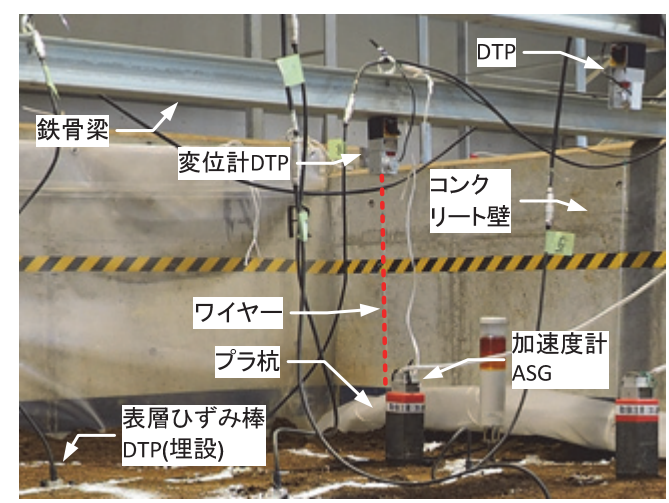

図-12 鉄骨梁を不動点にDTPで沈下を計測する様子

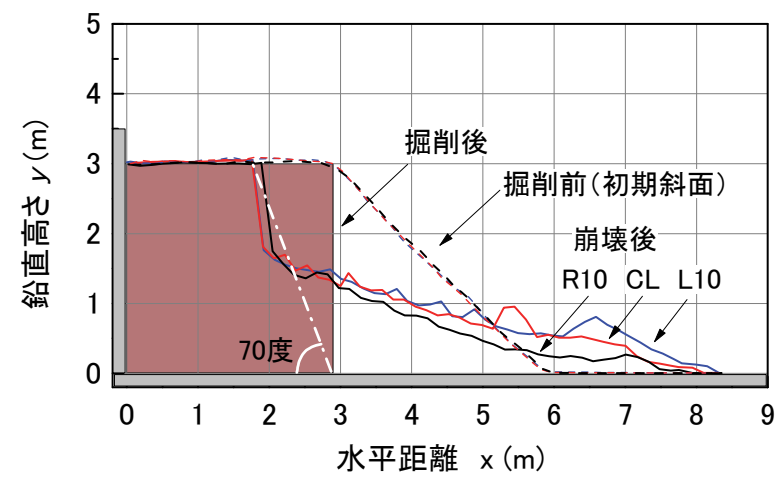

図-14 崩壊前後の斜面形状
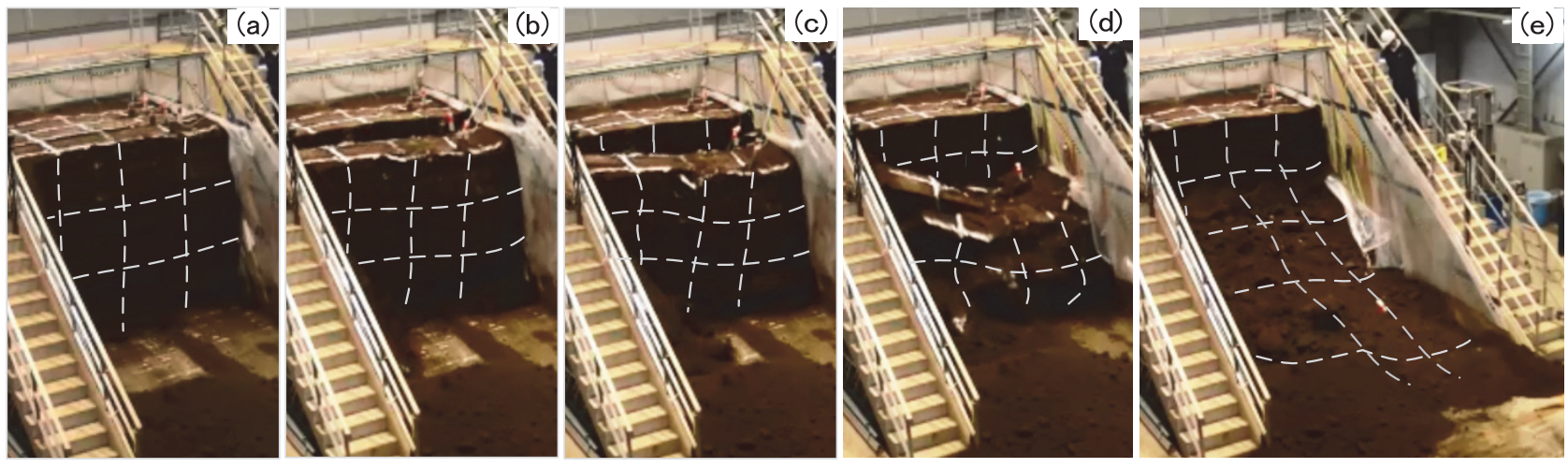

図-13 崩壊する斜面の様子(約5秒間)

反応は微小であるが明確なことが確認された. 反応の実 験值と解析值を比較した一例では差が $0.4 \%$ でった ${ }^{10)}$.

検知部は直径 $\phi 10 \mathrm{~mm}$, 厚さ $1 \mathrm{~mm}$ のステンレスパイプ であり，その曲げ岡性は5.46 $\times 10^{7} \mathrm{~N}$ mmである ${ }^{10)}$ ，その中 央から両端に向かってそれぞれ $25 \mathrm{~mm}$ 位置に4枚のひ ずみゲージが対向するように貼り付けられている，その リード線を4アクティブゲージ法で結線し，曲げ変形に 対する反応を出力させた. ステンレスパイプは而候性の 熱収縮チューブで被覆してひずみゲージを保護した。

MPSの検定では持ち梁条件で端部に荷重を載荷して曲 げ変形させた。ここで，図-11(a)に示すようにMPSの長 さLに対する端部のたわみsを式(1)のように換算せん断ひ
ずみ $Q \%$ と定義する.

$$
\theta(\%)=\frac{s}{L} \times 100
$$

ひずみゲージからの応答ひずみ（ $(\mu \varepsilon) と \theta 0$ 間には良好 な直線関係が認められ，その感度は $\theta$ が $1 \%$ に対して, $r$ は約650 $\mu \varepsilon$ の出力であった ${ }^{11)}$. したがって, MPSは土の 小さなせん断変形に敏感に反応するセンサーである.

\section{(2) 崩壊過程の計測}

崩壊に至るまでの変化を記録するために3種類のセン サーを図-11(b)のように配置した。変位計(DTP)はR10の 列に $0.8 \mathrm{~m}$ 間隔で2箇所に設置して沈下量を計測した. そ 
の計測方法は伸縮計による移動計測 ${ }^{12)}$ 参考にDTP本体 を不動点側に置き，天端上のプラ杭を可動点とした．不 動点は図-12のようにコンクリート擁壁に渡した鉄骨梁 とし，DTPのワイヤーをプラ杭の頂部に結合させた。図 -11(a)と(b)に示した位置はこの可動点である.

傾斜角の計測には加速度計(ASG)を用いた。 これは, ダンピングオイルが充填されたひずタゲージタイプの傾 斜計は一般的に反応が緩慢なためであり，本実験では反 応の即時性を優先して加速度計を選択した. ASGはプラ 杭頂部に取り付けておりDTPの可動点と共有させた.

表層ひずみ棒(MPS)はR15，R05，CLの3列に2段で設置 し計6個である．表-4はセンサーの種類と計測 $1 \mu \varepsilon$ 当たり の物理量を応答感度として示す．実験の様子はビデオ撮 影するとともに，センサ一からの出力も同期させて計測 した，以上のように，本研究では目視と計測による監視 について予兆把握の可能性を調査した。

\section{(3) 掘削による崩壊の再現}

図-10 は実大斜面を部分掘削する様子を示す．図-11(a) と(b)はその立面図と平面図を示す，掘削は(b)図に示す ように幅 $4.0 \mathrm{~m}$ の斜面のうち先に幅 $3.0 \mathrm{~m}$ の部分に対し て行った. なお，斜面の高さは先の遠心模型実験で調べ た限界高さ $2.8 \mathrm{~m}$ よりも大きい $3.0 \mathrm{~m}$ であった．掘削は S1 から S8までの 8段階で実施した. (a)図に示すように, 第一掘削(S1)は法肩から垂直に深さ $1.0 \mathrm{~m}$ までを掘削し た. その後, S2 から S7 のように深さは異なるが上から 下に向かって段階的に掘削を進めた. 最終掘削の S8 で は，L10 から斜面に向かって左側に $0.3 \mathrm{~m}$ 幅で徐々に掘 削して溝部を横方向に拡大させた。 その掘削中に土の場 内移動を行ったため途中約 15 分の休止を含んだ. その ため S8 の前半と後半をそれぞれ S8a と S8b と整理した. それ以外の掘削は 30 分のインターバルを標準で確保し, データはS1から崩壊までの間，連続計測した。

図-13 は斜面が崩壊した約 5 秒間の様子を 5 枚の連続 写真で示す．崩壊は S1 の掘削開始からの総経過時間が 4 時間 40 分頃に発生し, それは S8b 終了から約 23 分後 であった。(a)図から(b)図までの間に天端で亀裂が生じ ており，先の図-11(b)に緑色と斜線で示したブロック A の部分はその箇所を示している. (c)図ではさらに段差 が増大しているが，この段階までは崩土がほぼ塊のまま 移動している。そして, (d)図から(e)図では塊が分割し ながら落下し，急速にブロック A と B 両方が崩壊に至 る.なお，図-11(b)の側面のブロック B が押さえ盛土の ように斜面を部分的に支持したため， L 列側は R 列側に 比べて僅かに遅れて崩壊している，しかしながら，最終 的な崩壊形状は図-11(b)にも図示したように実大斜面の 全幅に渡るものであった。溝の肩付近には崩壊前に細い 亀裂は生じたものの明確な段差は直前まで認められず,
目視での危険把握は困難であった。

崩壊前後の実大斜面に対し，図-11(b)の L15 列から R15 列までの 7 列をレーザー変位計でスキャンし，その 形状を計測した．図-14 は L10，CL，R10 の断面を示す。 点線は掘削前の初期形状を示し, 塗りつぶし部が掘削後 の実大斜面を意味する。実線は崩壊後の形状を示すが, R10，CL，L10 の曲線はほぼ一致しており最終的な崩壊 形状は 2 次元的であった。

すべり面は天端から鉛直高さ $y$ が $1.6 \mathrm{~m}$ までの間でほ ぼ垂直に生じているが， $y<1.6 \mathrm{~m}$ では崩土が堆積してい るためすべり面の形状を確認することはできない. 法先 と天端のすべり発生位置を結んだ直線の平均角度は約 70 度であった。

すべりが 2 次元的となった原因はブロック $\mathrm{B}$ の部分の 高さが最大 $3 \mathrm{~m}$ なのに対して幅が $0.7 \mathrm{~m}$ と薄くその押さえ 効果が限定的となったことが挙げられる. また, 切り取 られたブロック B の側面がほぼ垂直であったことも安 定を低下させた原因と考えられる.なお，MPS の設置 が崩壊形状に与えた影響は限定的であったと考えており， その理由は直径 $10 \mathrm{~mm}$ の MPS は斜面幅 $4 \mathrm{~m}$ に対して十 分に小さいことと，23 kPa で締め固めた土試料は依然軟 らかく MPS 貫入後にも亀裂等の発生は見られなかった ためである。

\section{5. 崩壊予兆の解析}

\section{(1) 反応の推移}

図-15 は 3 種類のセンサーの計測結果であり，掘削開 始から崩壊に至るまでの反応を示す。ここに示した2つ の曲線はブロック A 内の溝の肩から 2 段に配置したセ ンサーの反応である。横軸は実験開始からの総経過時間 $T$ を示し, S1 から S8 までの掘削タイミングも破線で示 す.なお, S8 ではセンサーの反応を見ながら 2 回に分 けて掘削したためそれぞれ S8aと S8bとしている. 各セ ンサーの正負は図-11(a)に示したとおりである. 溝壁部 は総経過時間 $T$ が約 $4.6 \mathrm{hr}$ の時に崩壊したが，これは最 終掘削の S8b から約 23 分後であった. 各センサーには 崩壊までの反応が現れている.

変位(沈下) $u$ は溝寄りに設置した DTP1 が S6 後から増 加を示す. S8b の掘削終了後も值は増加を続け, 崩壊直 前には加速度的に増加している. 一方, DTP1 からさら に $0.8 \mathrm{~m}$ 離れた DTP2 も S6から僅かな反応を示すものの その増加は明確でない。これは DTP2 の設置位置が崩壊 エリア(ブロック A)の外側だったためと見られ，崩壊時 の反応はDTP1に比べると極端に小さい.

傾斜角 $a$ は ASG1 と ASG2 共に曲線が下に凸の形状を 呈する共通した反応が現れている. その増減による值の 差は溝から奥側の ASG2 の方が大きく, S8a と S8bのそ 


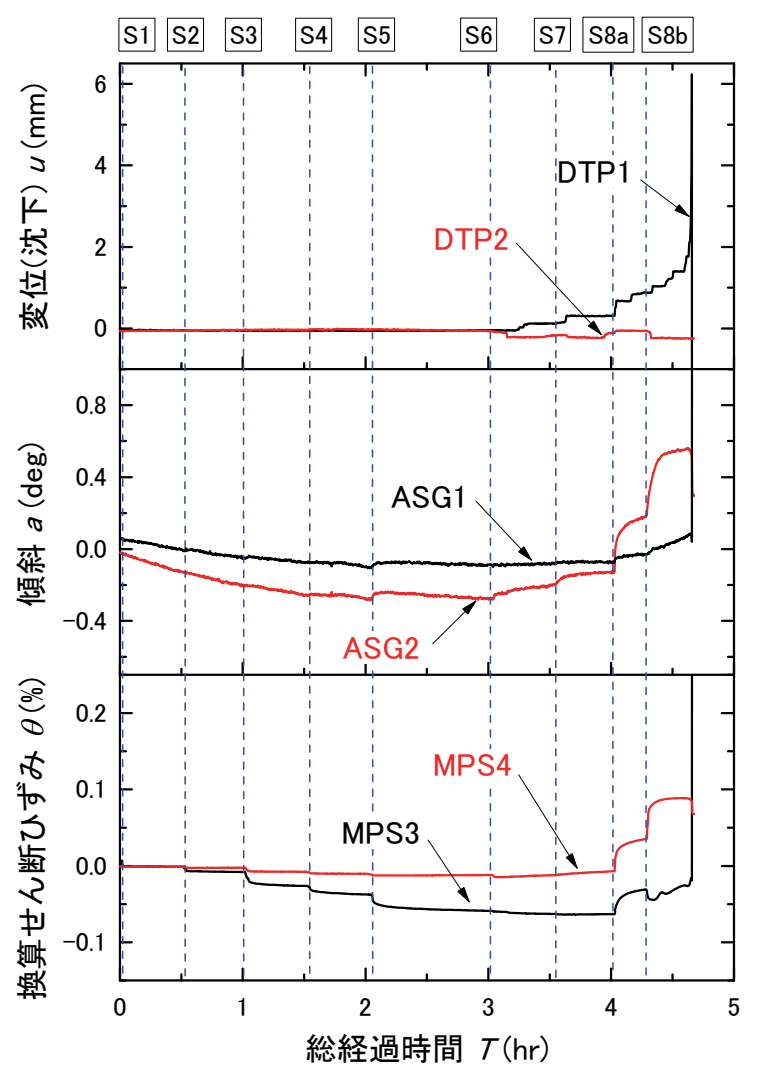

図-15 崩壊に至るまでの各計測の比較

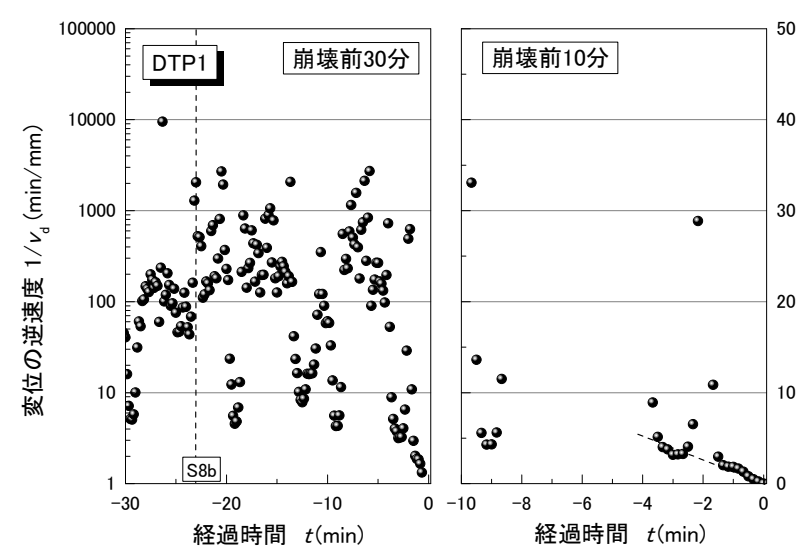

(a) 変位u（DTP1）の逆速度 $1 / v_{\mathrm{u}}$

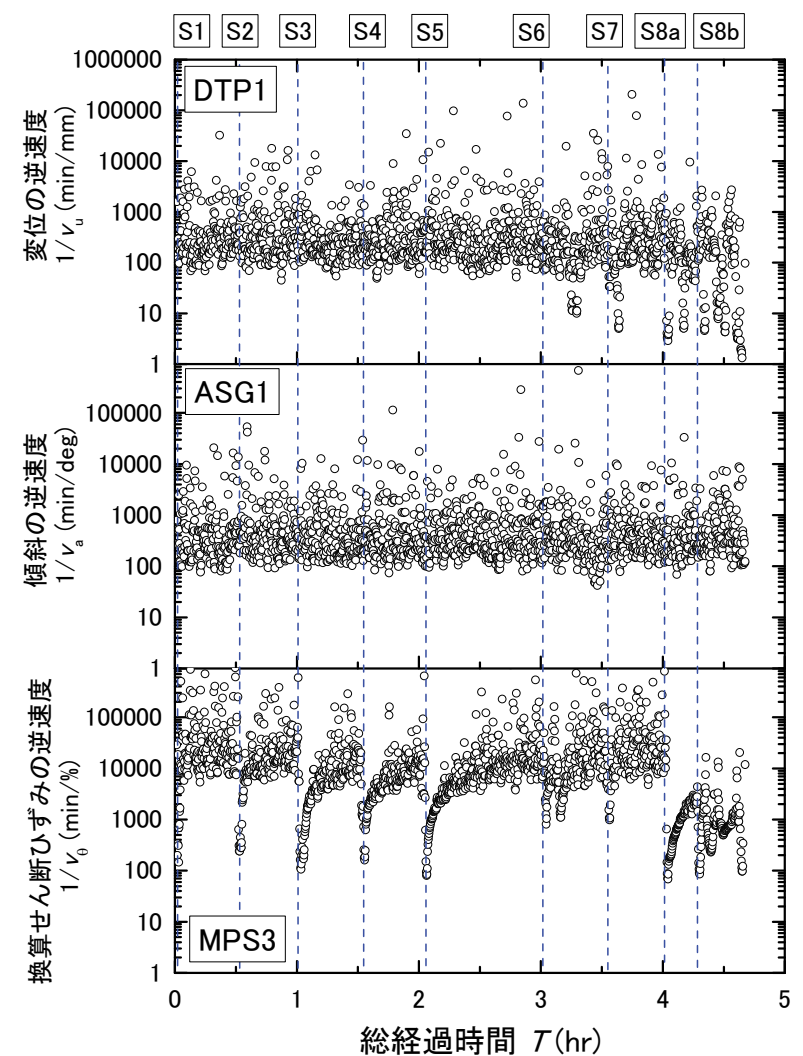

図-16 溝の肩に設置したセンサーの増加速度の逆数の推移

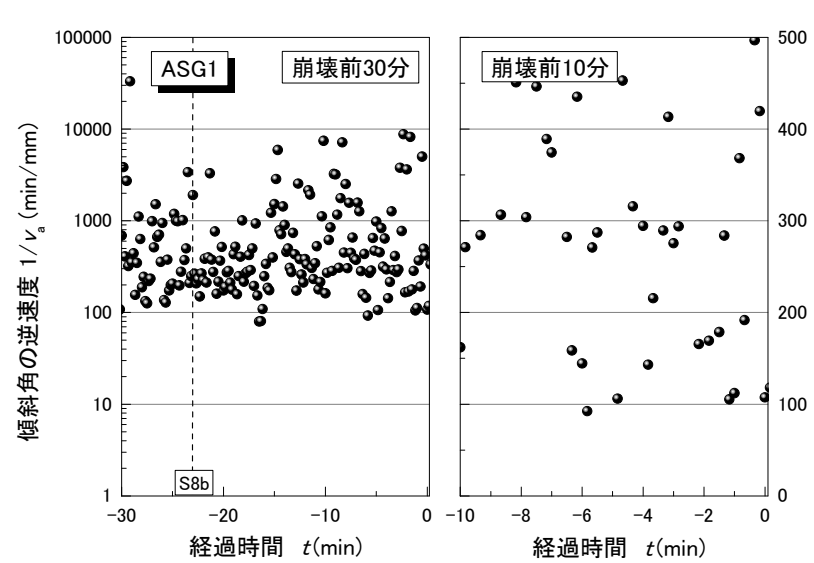

(b) 傾斜角a（ASG1）の逆速度 $1 / v$ a

図-17 变位と傾斜の速度の逆数(逆速度)

れぞれに対応して值は一旦増加しその後収束する変化を 繰り返す。一方, 溝寄りの ASG1 は増減が小さいものの 崩壊時に值は急増し，その発生が明確に捉えられている。 なお，S8a と S8b の ASG2 に見られる傾斜(前倒れ)につい ては後の(3)項で水平方向のひずみとの関係から改めて 考察する.

MPSによる換算せん断ひずみ $日$ は $0<T<4 \mathrm{hr}$ において (S1から S8aにおいて)MPS3 と MPS4共に曲線が下に凸の 形状を呈しており ASG と反応が一部類似している，日の 減少は(マイナス側の増加は)図-11(a)に示した変形モード

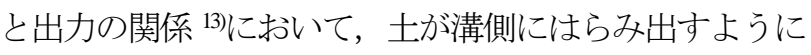
変形(溝側に凸の変形)したことを意味する. しかしなが ら， S8a 以降， $\theta$ は正の増加に転じており，お辞儀をす るようなモードに推移(溝側に凹の増加)した。 すなわち， トップリング的な崩壊に推移した。掘削部からの離隔が 等しい MPS4 と ASG2では，増加と収束の様子が S8a 以 降良く一致し，特に，DTP1 と ASG1 と MPS3 には S8b 以降，共にクリープ的な増加が見られる.

過去に行った斜面実験 11), 14)では崩壊に至るまでの $\theta$ こ 一貫した負の増加が発生し, その後, 崩壊数分前からは 
増加が加速度的となる反応を記録した。一方，溝実験で は掘削時に負の増加が見られたものの崩壊前には正の増 加に転じている，反応が溝と斜面で異なった原因は MPS の貫入角度と貫入位置の違いによると考えられる。

斜面実験では，MPS を斜面部に設置しその角度は面 に垂直であった，その結果，MPS の延長線上に発達す るすべり面とはほぼ直交する位置関係 ${ }^{14}$ となっていた.

一方，溝実験では溝壁部でなく溝の肩(天端)であったた め MPS とすべり面はほぼ平行な位置関係となった。 そ のため MPS は土の水平方向のひずみ差によって曲げ変 形したと考えられる. なお，各測定值は微小なことから 整合性を十分検証できておらず，この点については今後 の課題と考えている.

\section{（2）計測値の増加速度の逆数}

福直は伸縮計の移動速度の逆数に着目し，その時系列 変化から崩壊時間を予測することを提案した ${ }^{15}$. 本研究 ではこの考え方をせん断ひずみの速度に応用し，崩壊予 兆の把握が可能か検討した．図-16は反応がより顕著で あった溝寄りに設置したDTP1とASG1とMPS3について, $u, a$ 及び问速度の逆数とTの関係を示す。ここで単位時 間あたりの各増分をそれぞれの速度 $v$ と定義し, 各セン サーの識別は添え字で示寸. 本研究ではvを1分間当たり

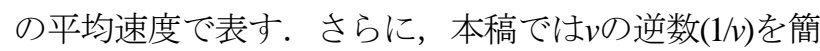
単のため以下では逆速度と呼ぶ(4).

変位DTP1の逆速度 $1 / v_{u}$ は $0<T<3 \mathrm{hr}$ ておいて $1 / v_{\mathrm{u}}>100$ $\mathrm{min} / \mathrm{mm}$ となっている.これは $v_{u}<1 / 100 \mathrm{~mm} / \mathrm{min}$ であるこ とを意味し，变位の速度は非常に小さかったことが分か

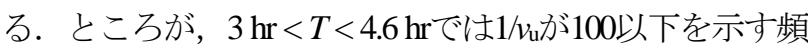
度が次第に多くなり， $4.6 \mathrm{hrでは} 1 /$ 况が1付近に減少してい る. 寸なわち，Vuは増加している．S8bにて掘削は終了 しており，これ以降地山に作用する荷重は一定であった が変位(沈下)は増加している．特に，崩壊前の約23分間 ではその速度が増減を繰り返しつつ, $1 /$ 山は次第に減少 している. 寸なわち, vは増加している.

この崩壊直前の変化を図-17(a)に拡大して示す. 経過 時間 $t$ は崩壊時刻を 0 として整理し，マイナスの值は崩壊 から遡った時間(何分前か)を意味する．同図の左側には 崩壊前30分の変化を対数スケールで示寸. 右側は崩壊直 前の拡大図であり，崩壊前10分の変化を示寸，なお，こ ちらの縦軸は線形のスケールに変えている. $-30 \mathrm{~min}<t<$

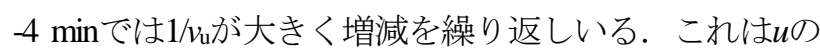
増加が階段状に記録されたためと見られ，伸張するワイ ヤーの摩擦による影響と考えられる. $t>-4 \min て ゙ は 1 / v に に$ 直線的な減少が見られいは加速度的に増加している.

再び図-16において傾斜ASG1の逆速度 $1 / v_{a}$ を見ると，0 $<T<4.6 \mathrm{hr}$ では值が $100 \mathrm{~min} / \mathrm{deg}$ 以上に一貫した分布が見ら れ，1分間当たりで整理した速度の值に掘削との明確な
関連は見られない，崩壊直前の変化を先の $u$ と同様に整 理して図-17(b)に示寸が， $-30 \mathrm{~min}<t<0$ において $1 / v$ ははほ ぼ100 min/deg以上に分布しtがゼロに近づいても減少して いない.したがって，、洧明確な増加は見られず本実験 では傾斜角から崩壊の予兆を判別することはできなかっ た.

換算せん断ひずみMPS3の逆速度 $1 / v_{\theta}$ はS1からS8bの全 てで一時的に減少する反応が現れている.これは昍の増 加を表す， $1 / v_{\theta}$ は減少後，再び増加して発散するように 分布している.このような増減は掘削に対応して繰り返 されており，MPSでは他の2つのセンサーに見られなか った速度変化が掘削開始から崩壊までの間で敏感に捉え られている.この $1 / v_{\theta} の$ 発散と収束の幅は, S1からS8aま での間でほぼ一定だがS8a以降で全体的に減少している. すなわち， $v_{\theta}$ に増加の兆候が現れている.

図-18は崩壊前の逆速度の変化を図-17と同様に整理し たものであり，本実験で設置した全6点のMPSの反応を 示す.MPSの番号と設置位置は先の図-11(b)のとおり, MPSの番号が奇数のものは溝の肩から $0.8 \mathrm{~m} の$ 離隔で設置

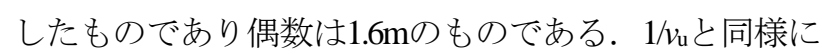
$1 / N_{\theta}$ にも崩壞前に值の増減が見られるものの, その周期 や減少開始の時間は必ずしも同じでない，6点の反応に 共通して崩壊前の $1 / v_{\theta}$ に直線的な減少が現れている。こ れは神が増加したことを意味し， て崩壊に至ったことがわかる。

一般的にクリープ破壊は定常増加(2次クリープ)から 加速度的な増加(3次クリープ)に推移して破壊に至る16, 17). MPS5々MPS6では-15 min < $<<-5$ minにおいて $1 / v_{\theta}$ の值がほ ぼ横ばいとなっている. 最終掘削のS8b後は地山の応力 が一定であったにもかかわらず， $\theta$ に増加が見られその 速度はほぼ一定となっている( $v_{\theta}$ が一定となっている).

これは, 換算せん断ひずみ暗次クリープ的に増加した ことを示寸. さらに, $-3 \mathrm{~min}<t<0$ における $1 / v_{\theta}$ の減少は $v_{\theta}$ の増加を意味することから， $\theta$ は加速度的に増加した ことがわかる，したがって，MPS5とMPS6にはクリープ 的破壊の傾向が明確に現れている.

表-5は各MPSの反応を崩壊前の速度と加速度的増加の 発生の視点から整理した結果を示す. 表中の $v_{\theta}>$ $0.01 \% / \mathrm{min}$ (すなわち $1 / v_{\theta}<100 \mathrm{~min} / \%$ )はこれまでの研究か ら2次的クリープの検出の目安とした值年である. 具体

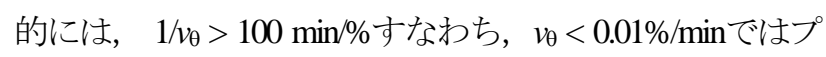
ロットした点の変動が大きくその信頼性は低く見られた ものの, $v_{\theta}>0.01 \% / \mathrm{min}$ では值が収束し, 計測は安定した. そのためMPSでは， $v_{\theta}>0.01 \% / \mathrm{min}$ 2次クリープ判別の 性能上の限界とした(閾值とした).

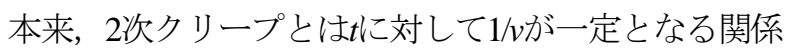
を指すが，今回の実験では図-12のように值は-30 min $<t$ $<-7$ minで幾分不規則に増減しており, 既往の研究11), 14)で 


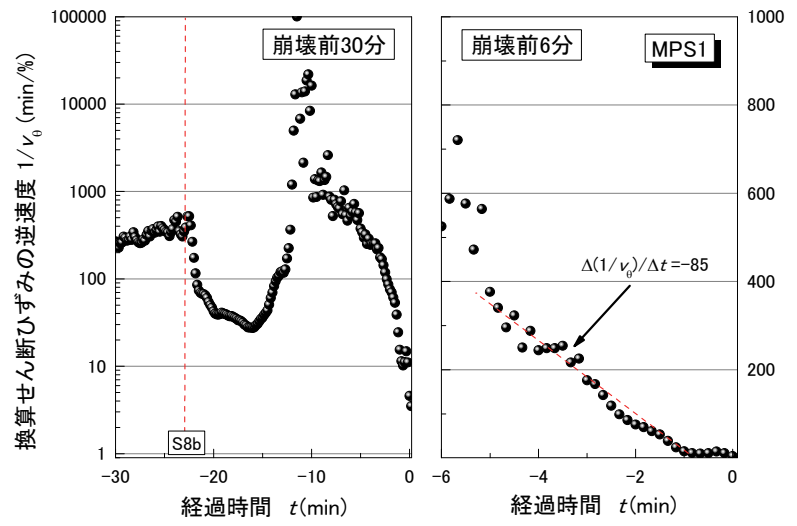

(a) MPS1の逆速度

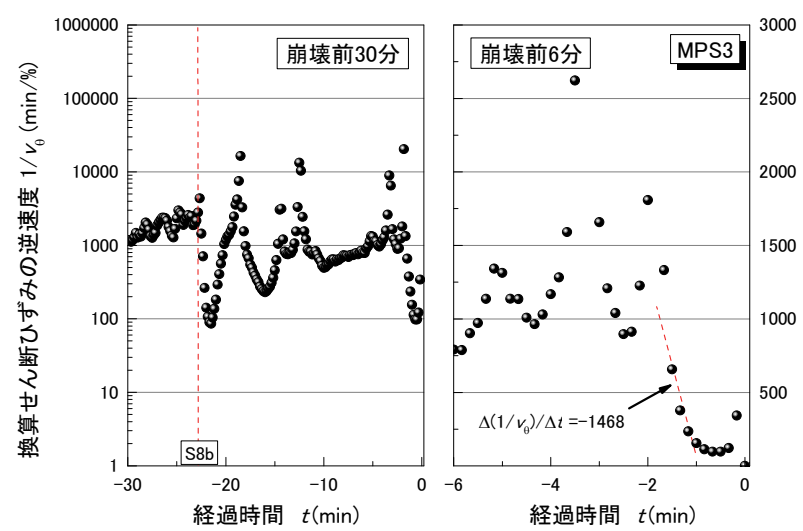

(c) MPS3の逆速度

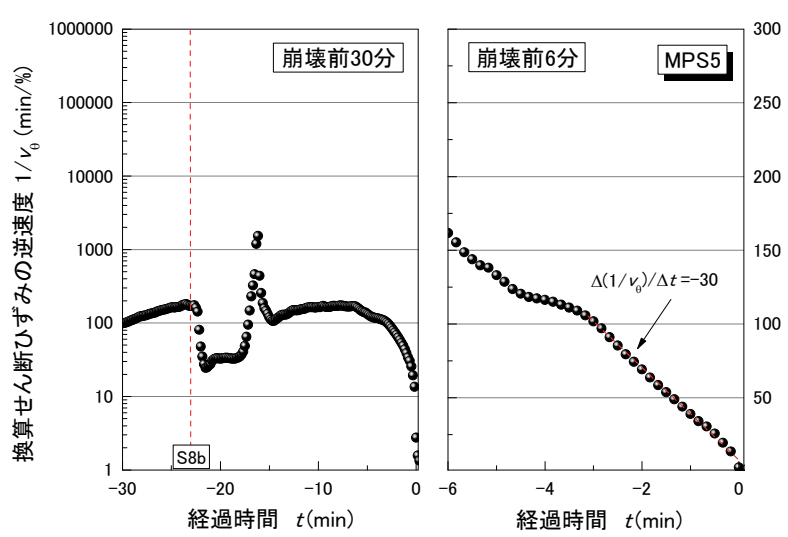

(e) MPS5の逆速度
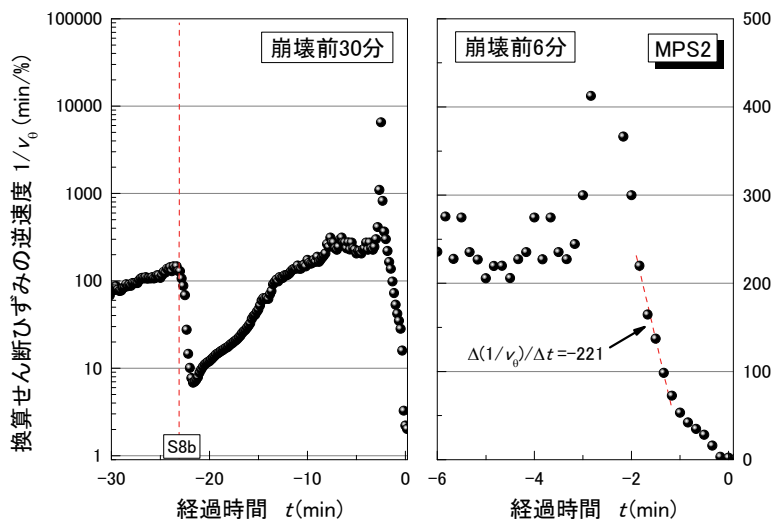

(b) MPS2の逆速度
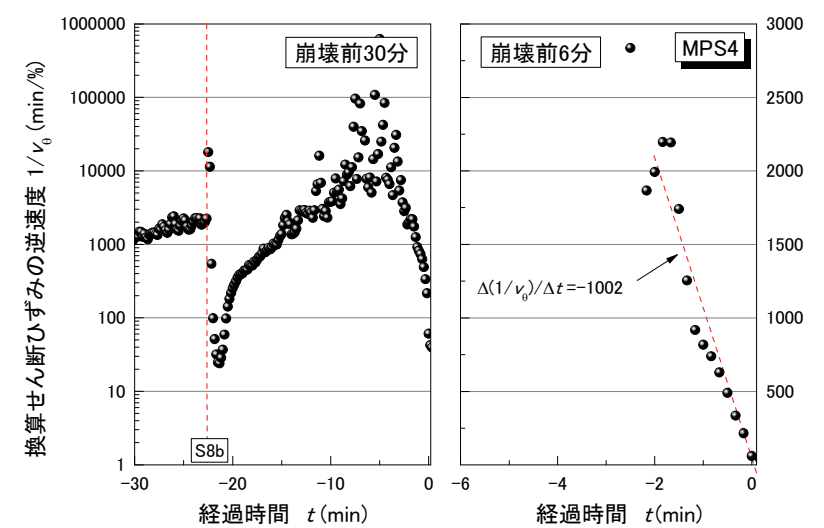

(d) MPS4の逆速度
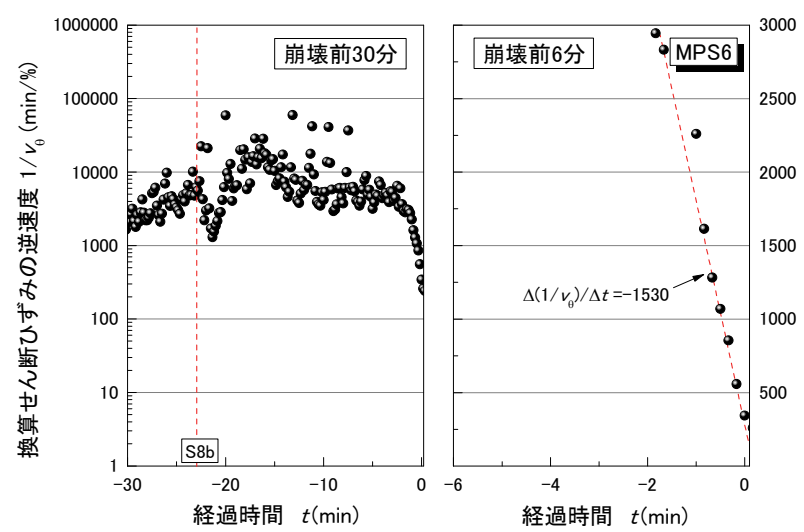

(f) MPS6の逆速度

図-18 換算せん断ひずみの速度の逆数(逆速度)

表-5 崩壊前のひずみ速度と加速度的な増加の状況

\begin{tabular}{|c|c|c|c|c|c|}
\hline 表層ひずみ棒 & 設置列 & $\begin{array}{l}\text { 溝からの距離(m) } \\
\text { (法肩からの距離) }\end{array}$ & $\begin{array}{c}v_{\theta}>0.01 \% / \min \text { となった時間(分) } \\
t_{1} \text { (崩壊何分前) }\end{array}$ & $\begin{array}{c}\text { 加速度的増加の開始時間(分) } \\
t_{2} \text { (崩壊何 分前) }\end{array}$ & $\begin{array}{c}\text { 逆速度の減少割合 } \\
C_{\mathrm{i}}=\Delta\left(1 / v_{\theta}\right) / \Delta t\end{array}$ \\
\hline MPS1 & \multirow{2}{*}{ R15 } & 0.8 & 2.3 & 5.2 & -85 \\
\hline MPS2 & & 1.6 & 1.3 & 1.8 & -221 \\
\hline MPS3 & \multirow{2}{*}{ R05 } & 0.8 & 0.6 & 1.5 & -1468 \\
\hline MPS4 & & 1.6 & 0.1 & 2.0 & -1002 \\
\hline MPS5 & \multirow{2}{*}{ CL } & 0.8 & 2.9 & 3.1 & -30 \\
\hline MPS6 & & 1.6 & なし & 1.8 & -1530 \\
\hline
\end{tabular}




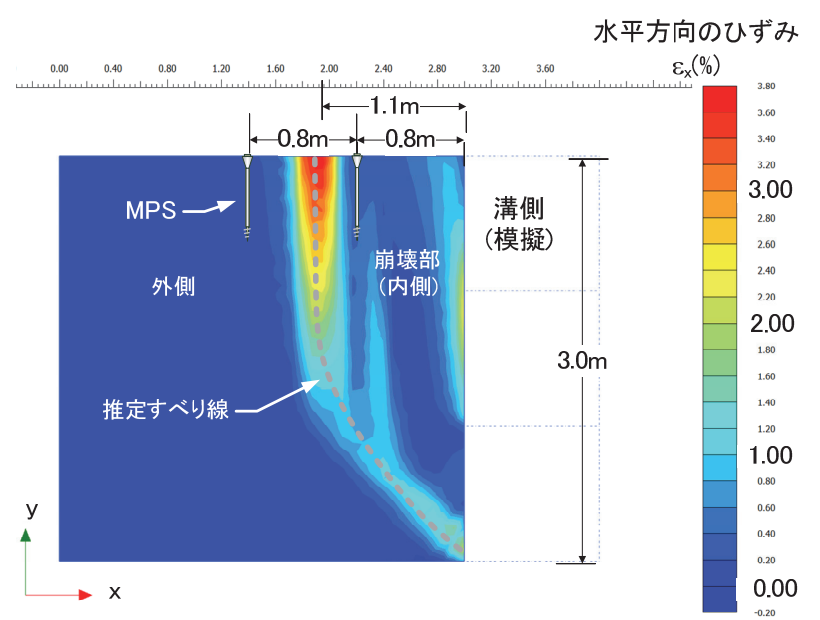

図-19 崩壊前に発生した水平方向のひずみ $2 x$

表-6 逆解析から推定した土のパラメータの值

\begin{tabular}{l|c}
\hline 単位体積重量 $\chi\left(\mathrm{kN} / \mathrm{m}^{3}\right)$ & 12 \\
\hline ポアソン比 $v$ & 0.25 \\
\hline 内部摩擦角 $\phi$ & 5 \\
\hline 弾性係数 $E\left(\mathrm{kN} / \mathrm{m}^{2)}\right.$ & 200 \\
\hline 粘着力 $c\left(\mathrm{kN} / \mathrm{m}^{2}\right)$ & 10 \\
\hline
\end{tabular}

見られたような ではなかった，そのため，ここでは便宜的に，崩壊から 遡って直近の $v_{\theta}>0.01 \% / \mathrm{min}$ となった時間(崩壊何分前

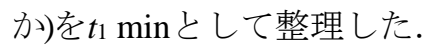

$t_{1}$ を同一の設置列で比較すると $0.8 \mathrm{~m}$ の (溝寄り側 の)MPSの方が值は大きく, 相対的に速く $v_{\theta}$ の増加が捉え られている.さらに， $t$ 亿対する $1 / v_{\theta}$ の直線的な減少を $\theta$ の加速度的増加(3次クリープ)の発生と見なし，その時 間 MPSの方が值は大きく, 1/ $v_{\theta}$ の減少割合Cは小さかった. 天端に現れた崩壊ブロックのすべり線は溝から 0.9 m〜 $1.1 \mathrm{~m}$ であったことから，MPSの反応はこの崩壊ブロック の外側と内側による差と見られ，内側の方が崩壊直前の 反応は大きくかつ早期に現れることがわかった.

\section{(3) 地表面付近の変化による危険把握}

溝の肩から $0.8 \mathrm{~m} と 1.6$ m離れた位置で計測した沈下, 傾斜及びせん断ひずみの3つの值には先の図-15に示した とおり掘削に伴う共通した反応が見られた。 しかしなが ら，崩壊前の約23分間を除けば，掘削に伴う各值の変化 は小さく, 反応は緩慢なものであった.

図-16に示した各 $1 /$ は掘削S1からS7まで発散するよう に分布した。これは，vがほぼゼロであることを意味し， この段階ではクリープ的な変化が見られない. だが, S8a S S8bでは 掘削終了後の速度に変化が現れている. 図-17と図-18に示したように，S8b以後に対応する $t>-23$ $\min て ゙ は ~ 1 / v_{u}$ と $1 / v_{\theta}$ は共に減少している．特に，溝寄りに
設置したDTP1も崩壊2分前には1/vが゙直線的に減少して3 次クリープを示した．同様な変化は同じ離隔にあった MPS2，MPS4及びMPS6にも見られ，t专ほほぼ2分で一致 した. したがって，崩壊前の特徵的な変化がDTPとMPS に共通して確認された.

図-19は汎用ソフトウエアPLAXISを用いた有限要素解 析による水平方向のひずみ致の分布を示す．使用したパ ラメータの值は表-6のとおりであり，これは崩壊高さと 崩壊範囲が一致するように試行して得られた結果である. \&の值は溝の肩から $1.1 \mathrm{~m}$ 付近で大きくなっており，実験 に見られたすべりの発生位置とほぼ一致する。 また， $8 x$ を水平方向に比較するとすべり位置から離れるに従って 值は急激に減少しており, 特に, 崩壊部の内側に比べて 外側では減少が顕著である。これは，先の図-15に示し たMPS3とMPS4の比較において，わずかであるが内側の MPS3の方が值の増減は大きかったことと一致する.

深さ方向の比較では表面付近の $2 x$ の值が大きい. 図15のT $>4$ hrにおいて 地正の増加を示しており，その極 性は図-11(a)に示したプラス $(+) の$ 変形モードと符合する. また，先の図-13の連続写真で壁部がトップリングする ように崩壊していることからも図-19の\&が深さ方向に減 少する分布は概ね実験を再現しているように思われる. 加えて, 図-15のASG2の増加はこの玉によってプラ杭が 傾斜したためと考えれば説明ができる.したがって, MPSが捉えた反応はを ずみに曲げ変形したものと考えられる，なお，崩壊に際 して表面に生じた亀裂は溝の肩から約 $1.0 \mathrm{~m}$ 位置であ ったことから，各センサーの反応は寸べり線を挟んだ極 めて接近した位置での計測結果であったことに留意する 必要がある。

以上より，溝の肩付近に設置したMPSから崩壊前のク リープ的な増加が捉えられ，崩壊の予兆を簡易計測によ って検出できる可能性が見いだされた. 先に述べたとお り，本実験はMPSがすべり線に近接した位置での結果で あり，反応は比較的有利な条件で検出されたものと言え る. また，数值解析から崩壊部外側では距離の増加に伴 うと減少は著しい結果も得られており, 崩壊部から離 れた位置では増加を捉えられないことも予想される。 そ のためMPSの設置位置と危険検知の関係については引き 続き検討が必要である.

\section{6. まとめ}

本研究では，溝掘削工事において作業者が生き埋めと なる間接的原因の一つである逃げ遅れに着目し，崩壊危 険の事前検出について検討した. 本研究で明らかになっ た内容は次のとおりである. 
(1) 関東ロームを盛土して作製した実大斜面において溝 掘削を簡易的に模擬する実験を行ったところ，掘削 終了から約23分後に崩壊が再現された，崩壊までに 時間差を生じる土では作業者がその予兆に気づかず 逃げ遅れたり，安定していると見誤ったりするため 危険なことを指摘した.

(2) 再現された崩壊は土ブロックがトップリング的に壁 面から脱落する急激なものであったが，その予兆は 直前まで気がつかないほど小さなものであった。そ のため, 目視だけによる地山の監視では危険に気づ くのが遅れて被災する可能性が明らかとなった。

(3) 電気的計測による崩壊予兆の検出方法を実験的に検 討した. 計測箇所はガイドラインの「地山の点検」 に示された溝の肩付近の部分である.ここに新たに 開発した表層ひずみ棒(MPS)を設置してせん断ひず み $\theta$ 簡易計測するとともに既往のセンサーで変位 と傾斜角 $a$ を計測し, 反応を比較した.

(4) 掘削に伴う反応は各センサーに共通して見られたが, 崩壊前23分間を除けば変化は微小かつ緩慢なもので あった. 一方, 掘削終了後の変化には各センサーで 差が見られた。 その変化を1分間当たりの平均速度 で整理した $v_{\theta}$ と $v_{\mathrm{u}}$ には崩壊数分前から加速度的増加 が見られたｕの正確な計測には不動点を必要とす るがMPSでは単体で可能であり，計測は容易となる 利点がある.

以上のとおり, 本研究では溝の肩付近における危険把 握について実験的に検証した。すべり線が到達する表面 付近では水平方向のひずみが深さとともに減少するため, MPSはこれによって曲げ変形したものと考えられる．崩 壊前の日こはクリープ的な増加も確認されたことから, 危険把握の可能性が明らかとなった。 なお，本実験は MPSがすべり線に近接した位置での結果であったことか ら計測位置と危険検出の関係については引き続き検討す る予定である。

謝辞 : 本研究にご協力を頂いた東京都市大学の末政直晃 教授と伊藤和也准教授並びに本実験にご協力頂いた同大 元学生の竹内一起氏に深くお礼申し上げます.

\section{参考文献}

1) 伊藤和也, 豊澤康男, 堀井宣幸 : 切り土掘削工事現 場における斜面崩壊による労働災害の調査・分析, 労働安全衛生総合研究所特別研究報告, JNIOSHSRR-No.35 (2007), pp.7-18, 2008.
2) 安衛法便覧 I 平成 27 年度版 : 労働安全衛生規則, 労 働調查会, pp.1212-1214, 2015.

3) 土止め先行工法に関する手順と留意事項 土止め先 行工法とは：建設業労働災害防止協会，p.1，2006.

4) 安衛法便覧 III 平成 27 年度版 : 労働安全衛生規則, 労働調査会, pp.618-627, 2015.

5) 玉手聡, 伊藤直之, 遠藤明: 地盤の透水性と降雨強 度の関係に着目した斜面の表層崩壊に関する実験的 考察, 労働安全衛生総合研究所特別研究報告, JNIOSH-SRR-No.35 (2007), pp.33-58, 2008.

6) Mikuni, C., Tamate, S., Hori, T. and Suemasa, N. : Centrifuge model tests on seismic slope failure, Proceedings of the International Symposium on Earthquake-Induced Landslides, Springer, pp.501-510, 2012.

7)玉手聡：貫入型パイプひずみ計, 特許公報, P4942348, pp.1-11, 2012.

8) 玉手聡, 伊藤和也, SURENDARA B.Tamrakar : 表層 ひずみによる施工時斜面の崩壊監視に関する実験的 研究, 土木学会論文集 C, Vol.65, No.1, pp.1-18, 2009.

9) Tamate, S., Hori,T., Mikuni, C. and Suemasa, N. : Experimental analyses on detection of potential risk of slope failure by monitoring of shear strain in the shallow section, Proceedings of the 18th International Conference on Soil Mechanics and Geotechnical Engineering, pp. 1901-1904, 2013.

10) 玉手聡，遠藤明：斜面工事における簡易な安全監視 のためのスクリュー貫入型ひずみ計の開発とその適 用性に関する実験的研究, 労働安全衛生総合研究所 特別研究報告, JNIOSH-SRR-No.35 (2007), pp.107208, 2008.

11) 玉手聡, 堀智仁, 三國智温, 伊藤和也, 吉川直孝, 末政直晃 : 斜面の浅い部分のせん断ひずみ計測によ る崩壊予兆の把握に関する大型模型実験, 土木学会 論文集 C, Vol.69, No.3, pp.326-336, 2013.

12) 地盤調查法: 地盤工学会基準(JGS 1725-1955), 伸縮 計を用いた地表面移動計測方法, 地盤工学会, pp.443-450, 1999.

13) 三國智温, 玉手聡, 堀智仁, 未政直晃: 崩壊部周辺 における斜面表層のせん断ひずみ計測, 第 48 回地盤 工学研究発表会発表講演集, pp.1903-1904, 2013.

14) 玉手聡, 堀智仁, 三國智温, 未政直晃: 施工時斜面 における浅い部分のせん断ひずみ計測による崩壊監 視の検討, 土木学会論文集 C(地圈工学), Vol.70, No.2, pp.213-225, 2014.

15）福直輝旗 : 表面移動速度の逆数を用いた降雨による 斜面崩壊発生時刻の予測法，地す心゙り，Vol.22, No.2, pp.8-13, 1985.

16) 斉藤迪孝：斜面崩壊発生時刻の予知, 土と基礎, Vol.17, No.2, pp.29-38, 1969.

17) 斉藤迪孝: 斜面崩壊の予測について, 土と基礎, Vol.20, No.2, pp.13-19, 1972.

(2016. 9. 28 受付) 


\section{FULL SCALE MODEL TEST ON DETECTION OF POTENTIAL RISK OF TRENCH FAILURE BY MONITORING OF THE SHOULDER AREA}

\section{Satoshi TAMATE and Tomohito HORI}

Labor accidents frequently occur in trench excavations so that workers are buried of collapsed soil. Main cause of the accidents was luck of an installation of retaining walls to support the trench walls. In addition, workers failed to escape because they were not aware of an increase of the risk prior to failure. This study discusses on availability of simplified monitoring for prevention of the labor accidents. A full scale model test was carried out in a model ground composed of soft deposit of Kanto-loam and Compact strain meters of developed sensors were installed to measure increment of shear strain $\theta$ in shallow subsurface near the trench shoulder. Trench wall did not fail immediately after a completion of the final excavation, and 23 minutes of time lag existed prior to failure. The relationship between $\theta$ and the displacement shows good agreement in the increase. Similar reactions to the creep strain curve were observed in $\theta$. A couple of minute time could be provided for escape by identifying either 2nd or 3rd creep. A clear increase of $\theta$ was observed at the shoulder area when the trench became unstable. It was clarified that the potential threat of trench failure can be detectable by the monitoring. 